\title{
地震動の非定常スペクトル密度とその模式化 \\ TIME VARYING POWER SPECTRAL DENSITIES OF EARTHQUAKE MOTIONS AND THEIR MATHEMATICAL REPRESENTATION
}

\author{
後藤 尚 男*.北 浦 勝** \\ By Hisao GOTO and Masaru KITAURA
}

\section{1. まえがき}

構造物の耐震設計を確立していくためには，設計地点 に耐用期間中に来襲するであるら地震動のモデル化，基 礎一地盤系をも含めた構造物の動特性およびそのモデル 化, 予想される地震動に対するモデル化された系の応答, 破壊に対する照査の 4 段階のそれぞれを実験的・理論的 に追求していかねばならない。本研究は第 1 段階の地震 動のモデル化を, 特に地震動のパワースペクトル密度関 数***の非定常性に注目して考察したものである。

最近, 従来の震度法をそのままの形で適用することが 困難な柔構造物などの耐震設計においては，適当なモデ ルで表示された構造物に実地震動を入力として作用させ 応答計算によりその安全性を照査する場合が多くなりつ つある。このときすでに得られているある特定の地震動 記録のみでなく，構造物の立地場所に将来来襲すると予 想される地震動が入力として使用されることが 望まし い。ところで将来の地震動を予想することは一般に困難 な場合が多いので，過去に得られた地震記録を整理・解 析することにより実地震の持つ諸性質, たとえば地震動 の振幅特性や振動数特性, 地盤の動特性との関倸などを 把握し，これらの諸性質を反映した確率過程を人工的に 発生させるという試みがなされている(1),2)。地震のメカ ニズムが次第に明らかにされつつあり，強震記録が集積 されつつあるとはいえ，、まだ代表的な地盤・地質の地 震記録すら十分には得られていない現状を考えれば，こ のような人工地震波を予想地震波として, また地震動の ランダム性を評価するための同一の確率統計的性質を有 する地震波群として用いることは十分意味のあることと して肯定されよう。

人工地震波に関するこれまでの研究は多くの場合, 地

* 正会員 工博 京都大学教授 工学部交通土木工学教空 ** 正会員 工博 京都大学助手 工学部交通土木工学教室
震動を定常確率過程として职り扱うか，あるいはその振 幅特性の時間的変化にのみ考慮が払われるが，地震動の 振動数特性を表現するスペクトル密度は時間が経過して もあまり変動しないものとして考察が進められてきてい る。これは耐震設計において対象となる地震波形注地震 記録のうちの比較的加速度振幅の大きな部分であり，こ の部分のスペクトル密度が記録全体のそれに占める割合 がかなり大きいと考えられたからであらら。また非定常 性に関する数学的表現の複雑さとならんで, 実地震の本 質が完全につかめていなかったということも，振動数特 性の非定常性が然視されてきた理由の一つといえよう。

ところで地震動は振動数成分の異なる数種類の波動が 反射・屈折などを繰り返しつつ伝ぱしていく現象である から, 悠密には強震部分に拈いてもスペクトル密度は時 間とともに変化していると考えられる。最近ではこのよ らな観点から地震動を見直す研究がいくつか報告されつ つある。山原は実地震動のスペクトル密度と振幅特性の 時間的な変化を局所スペクトルの概念を用いてある時間 区間ごとに求め，パワーはもとよりスペクトル密度も地 震の初期, 中期, 末期においていちじるしく変化するこ

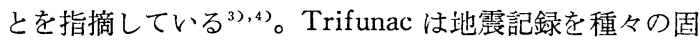
有振動数を持つ線形 1 自由度系に入力として与兄, 固有 振動数の違いによる応答の時間的変化の推移より, 地震 動の非定常スペクトル特性を地震の震源のメカニズム (source mechanism) や表面波などの伝ぱとの関連にお いて検討を加えている ${ }^{5), 6) 。 ~}$

ところで過渡振動や非定常不規則過程に関するスペク トル解析の理論も発達しつつあり, Page の Instantaneous Power Spectrum ${ }^{7}$, Priestley $の$ Evolutionary Spectrum $^{8)}$ ，時間平均ではなく集合平均の概念を用いて 定義する Generalized Spectral Density ${ }^{9)}$, 局所スペク トル密度など物理的数学的に論理のとおった定義がなさ

\footnotetext{
*** パワースペクトル密度関数のことを以後本論文では単にス ペクトル密度と呼称する。
} 
れている。しかし結果を直観的に理解しうる形で, かつ 物理的解釈が定常確率過程の自然的な拡張となっている こと，使用が容易であること，などの条件を満たす非定 常確率過程のスペクトル密度に関する統一的な定義はい まだ与えられておらず，個々の研究者が種々の定義を用 いているといら状況にある。

以上見たように地震動の非定常スペクトル密度に関し ては, 数学的な基礎理論の未完成のゆえもあって, その 分類とか非定常スペクトル密度が構造物の応答に及ぼす 影響, 特に入力レベルや入力の卓越振動数によって変化 する応答レベルに依存して，固有振動数の変化する非線 形系の応答への影響に関する研究はいまだほとんど行わ れていない。このような観点から本研究ではまず地震動 のスペクトル密度の時間的変化を一次元局所スペクトル 密度の概念を用いて求め, 変化の様子について検討する とともにその分類を試みた。つついてスペクトル密度が 時間とともに変化する地震動を確率過程で模式表示し, このような確率過程は地震動のスペクトル密度の時間的 変化が構造物の応答に及ぼす影響を確率統計的に検討し ていくための入力地震波となりうることを示した。なお このような確率過程を線形および非線形 1 自由度系に作 用させ, 理論解析やシミュレーションによって得られる 応答について検討を加えるとともに，実験によって理論 解析などの妥当性を確認しているので, これらの結果を 本論文に引き続いて報告する予定である。

\section{2. 地震記録の解析方針}

震源に比較的近い地点で観測される地震（近地地震） においては, 地震動を振動数成分や速さの異なる数種の 波動に分離することは容易でない。他方遠地地震の記録 には実体波と表面波の違いがかなりはっきりと現われて おり，振動数成分が明らかに異なっているという時刻を 指摘しやすい場合がある。このように振動数成分の時間 的変化の様子は記録により必ずしも一様でないが，本文 では解析の都合上地震動の確率統計的性質は時間に関し て比較的ゆるやかに変化するものとした。すなわちこの ことはある短い時間間隔内では地震動の確率統計的性質 はあまり変わらず，したがってその間では近似的に定常 であると仮定することを意味している。

非定常スペクトル密度に関しては 1. でも述べたよう に種々の定義がなされつつあるが，本論文では最も基本 的でしかも直観的に理解でき, 従来の定常解析の概念を 包含する局所スペクトル密度によって地震動の非定常ス ペクトルを求めた。すなわちスペクトル密度の時間的変 化を求めるため, 地震の加速度記録 $\ddot{z}(t)$ からある時刻 $t$ を中心に前後各 $\tau / 2$ 秒間の部分記録を取り出し, 各部
分記録は定常であるものとして時刻 $t$ のスペクトル密度 $S(f, t)$ を次式より求めた。

$$
\begin{aligned}
S(f, t)=\frac{2}{\tau} & {\left[\left\{\int_{t-\frac{\tau}{2}}^{t+\frac{\tau}{2}} \ddot{z}(t) \cos (2 \pi f t) d t\right\}^{2}\right.} \\
& \left.+\left\{\int_{t-\frac{\tau}{2}}^{t+\frac{\bar{z}}{2}} \ddot{z}(t) \sin (2 \pi f t) d t\right\}^{2}\right]
\end{aligned}
$$

ここに $f$ は振動数を表わす。上式において した極值が従来の定常過程におけるスペクトル密度の定 義である。 $S(f, t)$ を求める時刻 $t$ は地震記録のはじめ より 1 秒ごとの間隔とした。また $S(f, t)$ の計算時間す なわち部分記録の維続時間 $\tau$ は, 地震記録に含まれる周 期約 5 秒以下（振動数約 $0.2 \mathrm{~Hz}$ 以上）の成分を対象之 するため 5 秒とした。

なお本方法には次に記すような問題点がある。すなわ ち本方法は元の地震記録に長方形のデータウインドウを 乗じ，てなる時間区間で平均化操作を施していることに なるので, てが短いほど時刻 $t$ における地震動の特性を 表わしらるが，低振動数成分波にはいる誤差が大きくな る。一方 $\tau$ を長くとるとその区間内での定常という仮定 が成立しにくくなり，近似的に定常解析を行いうるとす る根拠を失うことになる。また他の 1 つは元の地震記録 をてという有限特間で打ち切ることによりスペクトル密 度に変形が現れるという現象である。すなわち振動数領 域における重なり効果とよばれるものであり, 振動数領 域において原信号に含まれていない振動数成分である側 带波を生ずるとともに, 分解能が低下する。この点を改 善するためには をを長くとるということも 1 つの方法で ある。これら 2 つの問題点を検討するために 3. におい てまず $\tau$ が $S(f, t)$ に及ぼす影響を調べ, 本研究で対象 とした地震記録は新潟地震の記録を除けば $\tau=5$ 秒とす ればほぼ満足しうる精度で $S(f, t)$ の時間的変化が明ら かになることを確認した。

\section{3. 地震動のスペクトル密度の時間的変化}

地震動のスペクトル密度の時間的変化を調ベるために 用いた地震記録は Table 1 および Fig. 1 に示すとお りである。これらのうち El Centro 1940, Olympia 1949, Taft 1952 と称される地震記録は強震記録としては比較 的古いものであり, 従来より代表的な強震記録として耐 震工学においてしばしば引用されているものである。ま た, 日本の地震はいずれも最近の 10 年間に得られたも ので, 1968 年十勝沖地震はその規模が大であり, 松代 群発とえびのの両地震は震源にきわめて近く, 新潟は砂 


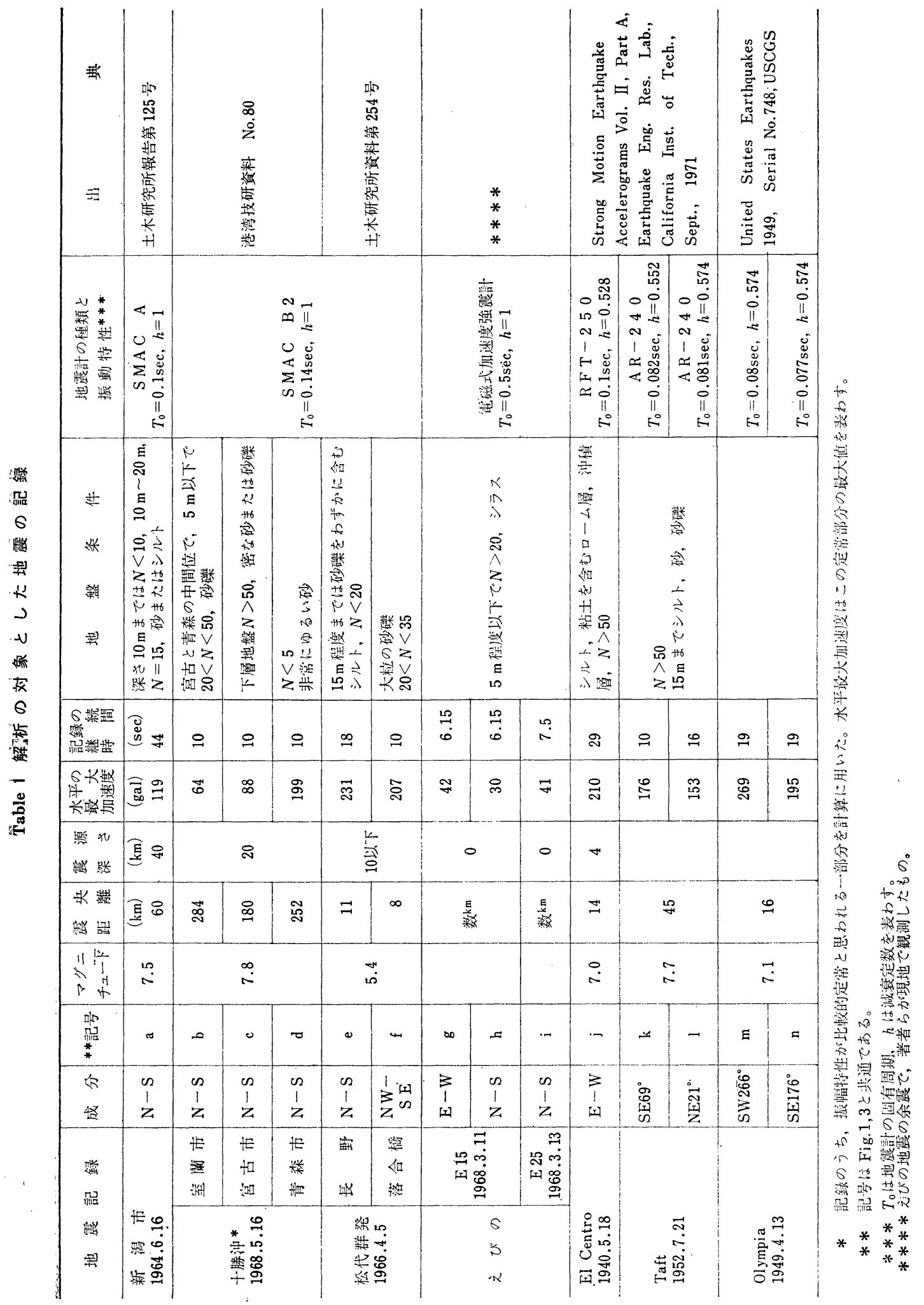



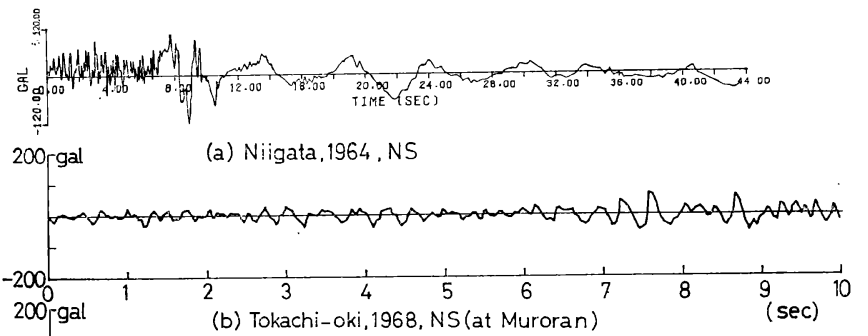

AlAara
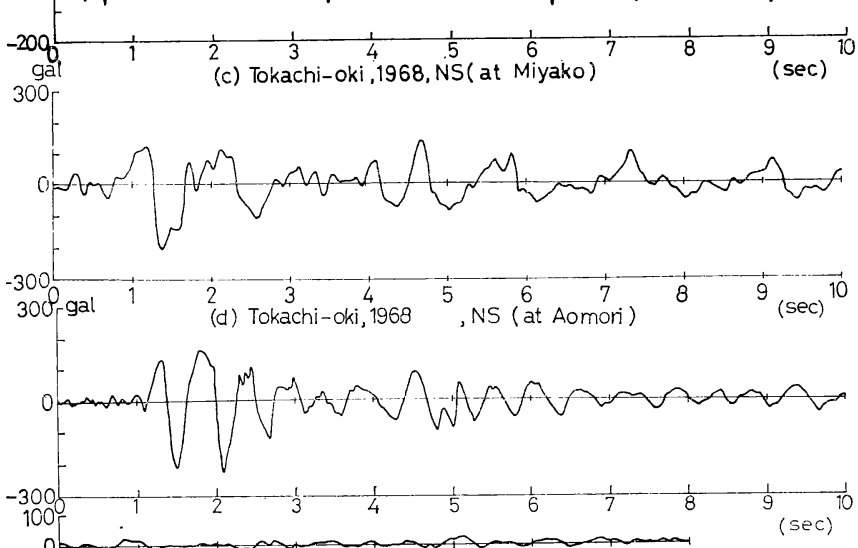

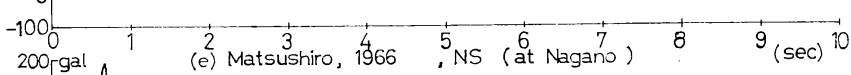

(f) Matsushiro,1966, NW-SE (at Ochiaibashi) ${ }^{9}{ }_{(\mathrm{sec})}^{10}$

$\$ 30$ gal

(g) Ebino(E15),1968, EW

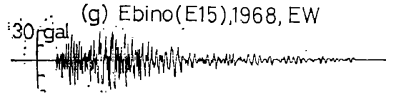

(h) Ebino(E15),1968, NS

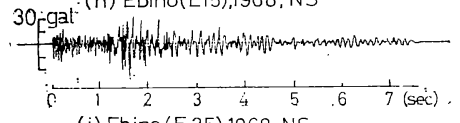

200 gal (i) Ebino (E 25), 1968, NS

-

200 ral $(j)$ El Centro, 1940, EW

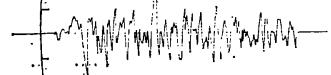

200 gal (k) Taft,1952,SE69

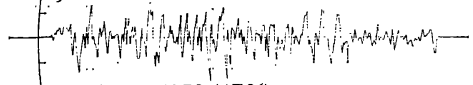

200-gal, (1) Taft, 1952, NE2⿰

200 rgal (m) Olympia, 1949, sw260

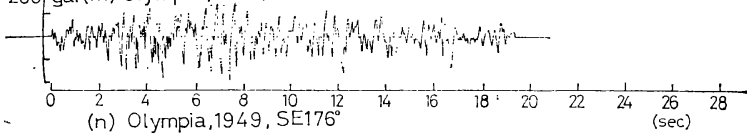

Fig. 1 解析の対象とした地震の加速度記録
質土の液状化の影響が現われているとい ら点にそれぞれの記録の特徴がある。

\section{（1）長方形ウインドウの時間区間 $\tau$ が $\boldsymbol{S}(\boldsymbol{f}, \boldsymbol{t})$ に及ぼす影響}

原加速度記録から取り出す部分記録の 長さ, すなわち長方形ウインドウの時間: 区間 $\tau$ が解析結果に及ぼす影響について 検討する。新潟の記録の場合は Fig. 1 (a) に見られるように記録の後半部分に は明らかに 5 秒程度の周期成分が卓越し ており，当然のことながら $\tau<5$ 秒なる ウインドウではこの周期成分（振動数成. 分）を正しく評価することは不可能であ. る。また地震動の確率統計的性質が記録 の途中で急変しているので, 部分記録が 定常であるという仮定が成立しない場合 がある。そこでこの記録に限ってかなり 明膫に振動数特性の異なっているとみな しらる時刻 (約 8 秒) の前後でスペクト ルを別々に計算することにした。

新潟以外で日本とアメリカの記録をそ れぞれ 1 個ずつ選び， $\tau$ の違いが $S(f, t)$. の形状に及ぼす影響を図示したものが Fig. 2 である。罒中たとえば $t=3.5$ と あれば時間記録のらちの 3.5 秒を中心と 
した $\tau$ 秒間の $S(f, t)$ であり, $t=$ all は記録の全継続時 間にわたって計算した結果を表わす。また $\sigma$ は各部分記 録の標準偏差值（単位は gal）を示す。なお各部分記録 のスペクトル曲線之振動数朝とで囲まれる面積が 1 とな るように規準化したスペクトル密度を規隻スペクトル密 度と称し， $S_{N}(f, t)$ と表わすことにする。 $S_{N}(f, t)$ は 各部分記録の振幅の大きさに防かわらず図の全面積が 1 であるので，亦る振動数成分の全成分に占める割合が容 易に読みとれるという利点がある。したがって図におい てはスペクトル密度として $S_{N}(f, t)$ を示してある。

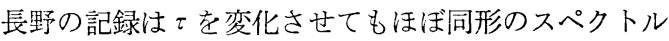
を有しており，てが 5 秒より小でもかなりよい情報が得 られる。この記録のように $S_{N}(f, t)$ が泳ぼ定常とみな しえて卓越振動数が比皎的高い（本記録は約 $2 \mathrm{~Hz}$ ) 場合 には，当然のことながら従来の解析のように記録の全継 続時間にわたって定常であるとする $S_{N}(f, t)$ を求めれ ば十分であり，しかもてを小さくとった $S_{N}(f, t)$ とも 一致する傾向にあることが確認されたことになる。これ らのことは新潟の持つ特徴とは対照的である。

El Centro の $S_{N}(f, t)$ は $\tau$ により若干変化が見ら れ，てが小さいほど側带波による平滑化の影響であると 考えられるが，スペクトルの山や谷の出入りが比較的ゆ るやかであり， $\tau$ の増大とともによりこまやかな変化が 認められる。 $\tau=5$ 秒以上ではその形に本質的な差は認め られず，ての増大すなわちより広範囲の時閒記録を含む ことによる差のみが形の違いとなって現われているとみ なしてよいようである。このことから El Centro に対し てはてを 5 秒ととるのが適当であると考えられる。

以上 3 種の記録に対する $\tau$ に関する考察から，加速度 記録から肉眼で読みとれる卓越周期が数秒以上といら特 殊な記録を除けば $\tau=5$ 秒のウインドウを採用すれば地 震動のスペクトル密度の非定常性をかなり的確にとらえ うるといえよう。

\section{（2）地震動スペクトル密度の時間的変化 (Fig. 3} 参照)

\section{Fig. 3 (a) 新潟地震の $S_{N}(f, t)$}

全継続時間にわたって定常であると仮定した 場 合の $S_{N}(f, t)$ は $0.3 \mathrm{~Hz}$ 近傍に大きなピークを持ち, $2 \mathrm{~Hz}$ 付近に第 2 のピークがあるが，高振動数成分も比較的混 入しており，この図 (Fig. 3 (a))を見る限りではやや ランダムな波形であると解される。一方加速度の時閒記 録を見ると 8 秒前後で明らかに振動数特性が異なってい るので，本記録に限り 8 秒の前と後で別々に $S_{N}(f, t)$ を求姉た。 $t=4$ 秒扎打る $S_{N}(f, t)$ は $0.3 \mathrm{~Hz}$ 付近㐳 ピークが見られるが, $t=$ all におけるときの $0.3 \mathrm{~Hz}$ 近 傍の値よりは小さく，かなりランダムな波形とみなしう
る。 $t=26$ 秒では $0.3 \mathrm{~Hz}$ 近傍の成分が非常に鋭、ピー クを持っているが，これらのことは加速度図において約 8 秒まではランダムな波形を示しているが，8 秒以後で は比較的周期の長い（振動数の低い）正弦波が卓越して いることと対応している。またこのことは従来から用い られている $t=$ all のスペクトル図では当然のことなが らスペクトルの構成が時間的に変化していることを表現 できないのに反して, 非定常なスペクトル解析によれば より正確に実地震波の持つ特性をとらえることができる ことを表わしている。

なお $S_{N}(f, t)$ の形状が急変する時刻（約 8 秒）は， この地震で注目を浴びるようになった砂の液状化現象が 記録の観測地点で始まった時刻を表わしているのではな いかと考えられる。したがって新潟の場合には卓越振動 数が時間とともに移動したとするよりは，ある時刻を境 にして異なる振動数成分の波が発生したと考えるべきで 㐫万う。

Fig. 3 (b), (c), (d) 1968 年十勝沖地震の $S_{N}(f, t)$ この地震に関しては室蘭, 宮古抢よび青森市における 記録を用いた。室蘭の $t=$ all の $S_{N}(f, t)$ は $2.7 \mathrm{~Hz}$ で 最大のピークを持っている。また非定常解析により求め た $S_{N}(f, t)$ は $t=$ all と同一の振動数のところでピー クを有しているが，值そのものは時間とともに若干変動 している。宮古と青森における $t=$ all の $S_{N}(f, t)$ はそ れぞれ $5.3 \mathrm{~Hz}$ と $1.1 \mathrm{~Hz}$ において最大の值をとるが, 非定常解析によれば記録の初期の部分において優勢であ る $5.3 \mathrm{~Hz}$ と $1.1 \mathrm{~Hz}$ のピークは時間の経過とともに低 振動数のほうへ移行し，かつ青森においてはピーク付近 の有するパワーの全体に占的る割合が大きくなっている ことが読みとれる。このことは加速度記録に掞いて青森 が時間の経過とともにやや周期化された波形を描いてい ることと対応していよう。またこのことは振幅特性が定 常であるとみなしえても(Table 1 の注参照)桭動数特性 は定常とは限らないことを示している。宮古の $S_{N}(f, t)$ の図形は時間とともにほぼ同一の形を保ったま低振動 数へと移行している。これら 3 個の実地震記録のスペク トル図は，たとえ同一地震であっても記録された地点が 異なれば，その波形はもとよりスペクトル特性の時閒的 変化のパターンも異なることを示している。

Fig. 3 (e), (f) 松代群発地震の $S_{N}(f, t)$

長野は $t=$ all において $1.9 \mathrm{~Hz}$ 付近で最大のパワーを 持っている。非定常解析においても $1.2 \mathrm{~Hz}$ から $1.9 \mathrm{~Hz}$ の間に顕著なピークをいくつか有し, 他の振動数成分に 比べて非常に大きく，加速度記録が時間仁かかわらずか なり正弦波に近い波形であることを示している。すなお ちこの $S_{N}(f, t)$ の形は時間とともに全体の大きさが沖 っくりと変動しているが，ピークとなる振動数の変遷は 


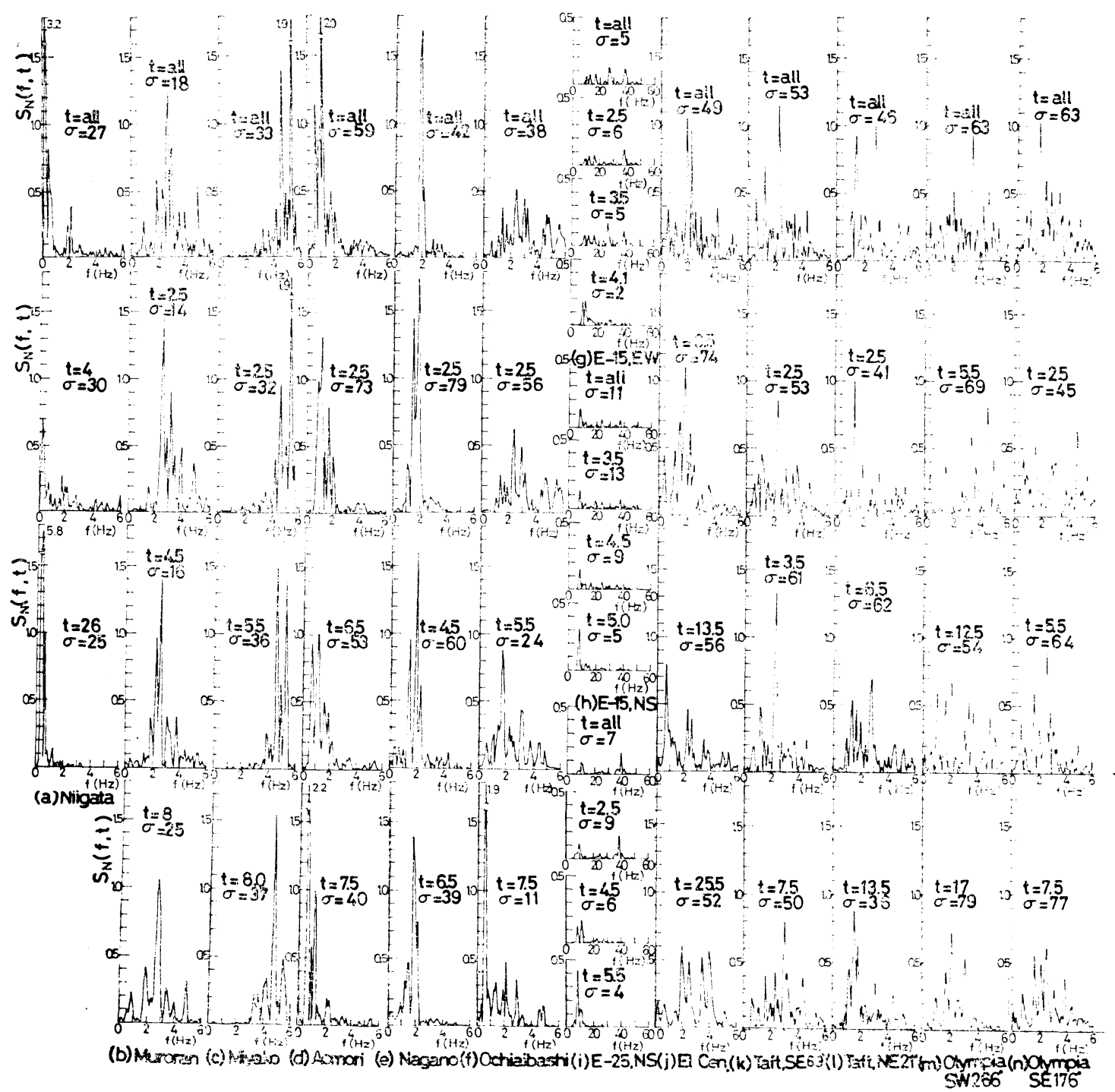

Fig. 3 実地震のスペクトル密度の時間的変化

ほとんざ見られない。したぶって長野の湯合注記録の全 継続時間にわたって定常之仮定してスペクトルを求的 ば，十分その振動数特性を反映した結果が得られること もわなる。一方落合橋の $t=$ all は $2.4 \mathrm{~Hz}$ にピークを 持つが，かなり広い振動数範囲でパワーを持っている。 ところが非定常としての解析では $t=2.5$ 秒において $2.4 \mathrm{~Hz}$ であるピークが時間とともに低振動数の方へ移 動し, かつピークとなる振動数の持つパワーの全成分に 占める割合が大きくなっている。

この場合も同一地震でも測定地点が異なればスペクト ル特性の時間的変化のパターンが異なる例である。

Fig. $3(\mathrm{~g}),(\mathrm{h}),(\mathrm{i})$ えびの群発地震の $S_{N}(f, t)$ えびのの 3 記録とも $t=$ all $~ S_{N}(f, t)$ と非定常解析
によるそれ上は比乾的よく傦ており，いずれも高振動数 成分が多い。またこれら 3 記録間でも大差疗く, 互いに 相似を傾向を示している。えびの地震のような局地地震 で震源にきわめて近い地点の記録は, 種々の振動数成分 が十分に分離していない状態の地震波動を表わすことに なるので，振動数特性の時間的変化が少なくまた地震の 違いによる $S_{N}(f, t)$ の差すほとんどないのであろうこ 考えら礼る。

Fig. 3 (j) El Centro の地震記録の $S_{N}(f, t)$ $t=$ all の $S_{N}(f, t)$ には $2 \mathrm{~Hz}$ の前後のピークを中心 に約 $1 \mathrm{~Hz}$ から $4 \mathrm{~Hz}$ までの成分が比較的均等に含まれ ており，かなりランダムな波形であることを示してい る。一方非定常解析によると $t=2.5$ 秒に扔いて $1.9 \mathrm{~Hz}$ 
付近にあったピークが $t=13.5$ 秒で約 $0.7 \mathrm{~Hz}$ のピーク にとって替わられ, さらに $t=25.5$ 秒では約 $2 \sim 4 \mathrm{~Hz}$ の間に数個のピークを有するようになっている。すなわ ちこの地震の $S_{N}(f, t)$ は時間とともにかなり変化して いるが，卓越振動数が高い（または低い）振動数領域へ 単調に上昇（または減少）していくといら傾向は見られ ない。ただし包括的に見れば $S_{N}(f, t)$ は全体として徐 々に高振動数領域へと移動している。これらのことは一 般に地震記録が持つと考えられている特性（時間の経過 とともに横波や表面波などのより低、振動数成分を有す る波動が到達し，したがってそのような成分が優勢とな る）を必ずしも十分に反映しておらず，震源が時間とと もに移動していることや波動が地艁内で複雑に反射屈折 を繰り返しつつ伝ぱしていることぶうかがえる。

Fig. $3(\mathrm{k}),(1)$ Tafî $の$ 地震記録の $S_{N}(f, t)$

Taft $N E 21^{\circ}$ の $S_{N}(f, t)$ はそのピークとなる振動数 やピーク付近のパワーの占的る比率が時間上上もに若干 変動している。パワーの占める比率の変化は加速度記録 に比較的正弦波に近、波形が卓越する部分とやや不規則 性の強い波形の部分とがあることと対応していよう。 Taft SE $69^{\circ} の S_{N}(f, t)$ についてもほぼ同様のことを 指摘しうるが，この場合には時間とともに高い振動数成 分がやや優勢上なり, その成分のパワーの全体に占める 割合が低下する傾向が見られる。このことは Fig. 3(k) をまとめ值した Fig. 4 からも明らかである。同図は

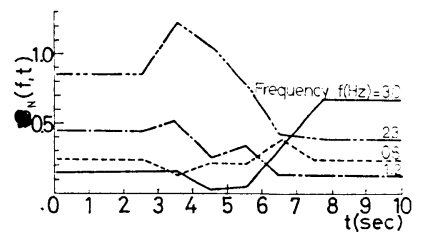

Fig. 4 スペクトル密度の時間的変化 (ある特定の振 動数 $f$ 成分の時間的变化, Taft $\mathrm{SE} 69^{\circ}$ )

Taft SE $69^{\circ}$ の $t=$ all における顕著なピークのみを取 り出し, その振動数成分の時間的な変化を困示したもの である。縦軸は $S_{N}(f, t)$ を表わしているので, 横軸の 時間 $t$ に対する縦軸の值はその時刻におけるある振動数 成分の持つパワーの全パワーに対する比率を示してい る。したがってこの図からも $t=2.5$ 秒においては 1.2 $\mathrm{Hz}$ や $2.3 \mathrm{~Hz}$ の振動数成分が多いこと, 時間の経過と ともにより高いすなわち $3.0 \mathrm{~Hz}$ の振動数成分が優勢と なること, 時間とともに顕著なピーク成分の值がほとん ど低下しており，よりランダムな波形に近づいていくこ とが明らかである。

Fig. $3(\mathrm{~m}),(\mathrm{n})$ Olympia の地震記録の $S_{N}(f, t)$ SE $176^{\circ}$ の $t=$ all における $S_{N}(f, t)$ は約 $1.6 \mathrm{~Hz}$
付近にピークを持つが，比較的広带域の振動数成分を含 んでおり, 全体としてはかなりランダムな波形であると いえる。ところが非定常解析による上時間の経過ととも に比較的平担なスペクトルが $2.5 \mathrm{~Hz}$ 付近にピークを持 つ形を絽て再び平担なスペクトルヘと，すなわちランダ ムな波形から正弦波に近い波形を経て再びランダムな波 形へと近ついている。 $\mathrm{SW} 266^{\circ} の S_{N}(f, t)$ も時間の経 過とともにランダム波から, 正弦波形へと変化している が, SE $176^{\circ}, \mathrm{SW} 266^{\circ}$ のいずれも卓越振動数の移動は 単調な変化ではなく，このことは種々の振動数成分を持 つ波動の到達や震源の時間的な移動などを意味している のではないかと考えられる。

\section{4. スペクトル密度が時間的に变化する 地震動の模式表示}

これまでの地震記録の解析に㧍い下，丽震設計におい 一対象上される加速度振幅の大きな部分にのみ注目して も，スペクトル密度法時間的に変化する場合の多いこと が明らかにされた。本項では, 地震動のスペクトル密度 の非定常性が構造物の応答に及ぼす影響京検討するため に用いる入力を，先に解析した実地震記録の結果を基に して人工的に発生させることを試みる。

\section{（1）地露動の模式表示}

先に得られた実地震動の非定常性のパターンを大別す ると以下のようになる。a）時間の経過とともに高い振 動数が卓越する(たとえば Taft SE $69^{\circ}$ )。b) 逆に低い 成分が優勢となる (十勝沖の青森)。c) 高い成分が卓越 したり低い成分が卓越したりする (El Centro)。d) 卓 越振動数はほとんど変わらない(十勝沖の室蘭)。また 各時刻の地震動の分散值で除して規準化したスペクトル 密度 $S_{N}(f, t)$ の形状自体の時間的変化は大きく分ける と Fig. 5 (a) に示すように卓越振動数が低くなるにつ れてランダム波形から正弦波形に近づく場合 (type I, たとえば松代の落合橋）と同図（b）のように時間にかか わらずほぼ合同な形で，ただその振動数領域のみが変わ

る（type III，十勝沖の宮古）という両者がある。

スペクトル密度が以上のように時間とともに変化する

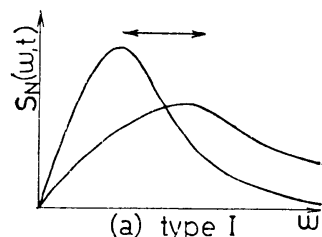

(a) type I

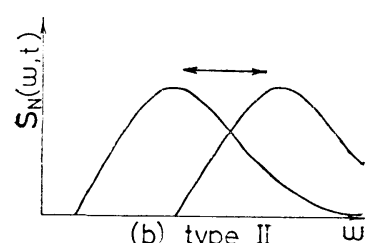

(b) type II
Fig. 5 実地震のスペクトル密度の形状 
場合の加速度を表わす時間関数としては種々の表現法が 考えられるが，ここでは後藤らの人工地震の表示法 ${ }^{1)}$ 拡張（式（3）のように $\alpha(t), \beta(t)$ を追加）し次式のよ うな確率過程を用いることにした。

$$
\left\{\begin{aligned}
\ddot{z}(t)=\psi(t) & \cdot g(\omega, \phi, t) \ldots \ldots \ldots \ldots \ldots \ldots \ldots \\
g(\omega, \phi, t)= & \lim _{N \rightarrow \infty} \frac{a}{\sqrt{ } N} \sum_{n=1}^{N} \cos \left[\left\{\alpha(t) \omega_{n}\right.\right. \\
& \left.+\beta(t)\} t+\phi_{n}\right] \ldots \ldots \ldots \ldots \ldots \ldots(
\end{aligned}\right.
$$

ここに, $\ddot{z}(t)$ は地震動加速度を表わす確率過程, $\psi(t)$ は時間 $t$ 亿関する確定関数で, $\ddot{z}(t)$ の振幅特性を規定 するいわゆる shape function, $g(\omega, \phi, t)$ は振動数成分が 時間とともに変化する確率過程であり, 振幅特性は定常 である, $a$ は加速度の単位を持つ定数, $N$ は正の整数, $\omega_{n}$ は確率密度 $p(\omega)$ を持つ確率変数 $\omega$ の実現值, $\phi_{n}$ は 0 と $2 \pi$ の範囲で一梯分布するランダム位相角, $\alpha(t), \beta(t)$ はスペクトル密度の時間的変化を表わす関数 であり， $\alpha(t)$ は主として type I の, $\beta(t)$ は主として type II の変化を表わす。なお $t=0$ における $\alpha(t)$ と $\beta(t)$ の值はそれぞれ $\alpha(0)=1, \beta(0)=0$ ととる。しから ばこのとき $g(\omega, \phi, t)$ の振動数を表わす項は $\omega_{n}$ のみと なる。したがって本表示法では $t=0$ における $\omega_{n}$ の分 布形 $p(\omega)$ が与えられれば, 時刻 $t$ における $\alpha(t) \omega_{n}+$ $\beta(t)$ の分布は一義的に定まることになる。

上式において地震加速度 $\ddot{z}(t)$ は振幅の大きさを規定 する時間 $t$ に関する確定関数 $\psi(t)$ と振動数成分が時間 とともに変化する確率過程 $g(\omega, \phi, t)$ の積で表わされ る。また, $g(\omega, \phi, t)$ は振動数の項, すなわち $t$ の係数 が式 (3)の\{\}内のように時間的に変化するように拉張 された余弦関数を，時間軸上でランダムにずらして加え 合わせたものとして表現されている。なお本論文におい ては, ある振動数成分の持つ絶対值そのものよりも，そ れの全振動数成分の持つパワーに占める割合を重視し, この比 $S_{N}(f, t)$ の值の大小でもってスペクトル密度の 時間的変化を評価してきた。したがって地震動の模式化 に当っても, 全パワーの時間的変化とスペクトル密度の それとを分離して考えるために地震動として式 (2)のよ うな表示法をとった。

\section{(2) $\boldsymbol{g}(\boldsymbol{\omega}, \boldsymbol{\phi}, \boldsymbol{t})$ のスペクトル密度亡 $\boldsymbol{p}(\boldsymbol{\omega})$ の関係}

式 (3) において $\alpha(t) \equiv 1, \beta(t) \equiv 0$ であれば $g(\omega, \phi, t)$ は定常確率過积となり, この場合には $g(\omega, \phi, t)$ のスペ クトル密度 $S_{g}(\omega)$ と確率変数 $\omega$ の確率密度関数 $p(\omega)$ とは相似形すなわち次式の関係の成立することがすでに 明らかにされている1。

$$
S_{g}(\omega) \pi=a^{2} p(\omega) / 2
$$

この式は任意の形状のスペクトル密度 $S_{g}(\omega)$ を持つ地
震波を人工的に発生させるためには, $S_{g}(\omega)$ と相似な確 率密度 $p(\omega)$ を持つ確率変数 $\omega$ を振動数として採用すれ ば，式（3）により求められることを示している。

次に一般に $\alpha(t), \beta(t)$ が $t$ の関数として与えられ る場合の $g(\omega, \phi, t)$ (以下, $g$ と略記する) のスペクトル 密度 $S_{g}(\omega, t)$ と $p(\omega)$ の関係について考える。2. にお いて地震動の非定常スペクトル密度を定義したが，この 定義を今の場合に適用すると, $S_{g}(\omega, t)$ は次のようにし て求められる。すなわち式 (3) で与えられる $g$ の時刻 $t_{1}$ におけるスペクトル密度 $S_{g}\left(\omega, t_{1}\right)$ は, $g$ を $t \neq t_{1}$ な る $t(-\infty<t<\infty)$ においても $t=t_{1}$ の状態で変動し続 けているという完全な定常確率過程と仮定することによ り，つまり $g$ を,

$$
\begin{aligned}
& g(\omega, \phi, t)=\lim _{N \rightarrow \infty} \frac{a}{\sqrt{N}} \sum_{n=1}^{N} \cos \left[\left\{c\left(t_{1}\right) \omega_{n}\right.\right. \\
& \left.\left.+\beta\left(t_{1}\right)\right\} t+\phi_{n}\right]
\end{aligned}
$$

と表わすことにより, 通例の定常確率過程のスペクトル 密度の定義を用いて求めることができる。このように非 定常スペクトル密度を定義すると, 定常確率過程の場合 の等式 (4) を求めるのとほぼ同じ方法により次式の関係 を得る。

$$
S_{g}(\omega, t)=\pi a^{2} q(\omega, t) / 2
$$

ここに, $q(\omega, t)$ は時刻 $t$ における確率变数 $\alpha(t) \omega+\beta(t)$ の確率密度。なお $t=0$ における $\omega_{n}$ は $t=t$ において は $\Omega_{n}(t)=\alpha(t) \omega_{n}+\beta(t)$ となるので, 確率密度に関す る変数変掺の関係式を用いることにより $q(\omega, t)$ すなわ ち $q\{\Omega(t)\}$ と $\omega$ の確率密度 $p(\omega)$ との関倸は次式で与 えられる。

$$
q\{\Omega(t)\}=\frac{1}{\alpha(t)} \cdot p\left\{\frac{Q(t)-\beta(t)}{\alpha(t)}\right\} .
$$

また, $S_{g}(\omega, t)$ を $S_{g}\{\Omega(t)\}$ と書き直すことにより式 (6) は,

$$
\begin{aligned}
S_{g}\{\Omega(t)\}= & \frac{\pi a^{2} q\{\Omega(t)\}}{2}=\frac{\pi a^{2}}{2 \alpha(t)} \\
& \cdot p\left\{\frac{\Omega(t)-\beta(t)}{\alpha(t)}\right\} \cdots \cdots
\end{aligned}
$$

となる。式 (8) 1 は式 (3) で与えられる非定常確率過 程 $g(\omega, \phi, t)$ のスペクトル密度 $S_{g}\{\Omega(t)\}$ と振動数の確 率密度 $q\{2(t)\}$ とは時間をパラメータとする集合平均 としてとらえると相似形となることを意味している。ま た $S_{g}\{\Omega(t)\}$ と $\omega$ の確率密度関数 $p(\omega)$ との関倸は式 $(8)_{2}$ で与えられる。

\section{（3） $\ddot{\boldsymbol{z}}(\boldsymbol{t})$ の共分散 $\boldsymbol{K}_{\ddot{z} \ddot{z}}\left(\boldsymbol{\tau}_{1}, \boldsymbol{\tau}_{2}\right)$}

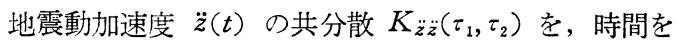
パラメータとする集合平均の考えを用いて次式のように 定義する。 


$$
\begin{aligned}
K_{\ddot{z} \ddot{z}}\left(\tau_{1}, \tau_{2}\right)= & E\left[\{ \ddot { z } ( \tau _ { 1 } ) - m _ { \ddot { z } } ( \tau _ { 1 } ) \} \left\{\ddot{z}\left(\tau_{2}\right)\right.\right. \\
& \left.\left.-m_{\ddot{z}}\left(\tau_{2}\right)\right\}\right] \cdots \cdots \cdots \cdots \cdots \cdots \cdots \cdots \cdots \cdots \cdots \cdots
\end{aligned}
$$

ここに,

$$
m_{\ddot{z}}(\tau)=E[\ddot{z}(\tau)]
$$

で与えられる。ところで $\ddot{z}(t)$ を構成する式 (3) の $g(\omega, \phi, t)$ の期待值は, $\cos \phi_{n}, \sin \phi_{n}$ の集合平均が 0 之 なることを利用して若干の演算を施すことにより 0 とな る。したがって $\ddot{z}(t)$ の集合平均 $m_{\ddot{z}}(\tau)$ も，

$$
m_{\ddot{z}}(\tau)=0
$$

となる。よって式 (9) は,

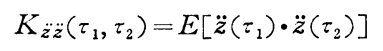

上なる。上式に式 (2) を代入し, $\cos \phi_{n}, \sin \phi_{n}$ および $\cos \phi_{n} \times \sin \phi_{n}$ の集合平均が 0 であることと, $\cos ^{2} \phi_{n} や$ $\sin ^{2} \phi_{n}$ の集合平均が $1 / 2$ となることを用いると, 結局

$$
\begin{aligned}
K_{z \dddot{z}}\left(\tau_{1}, \tau_{2}\right)=\frac{a^{2}}{2} \psi\left(\tau_{1}\right) \psi\left(\tau_{2}\right) \\
\quad \cdot \int_{0}^{\infty} \cos \left[\left\{\alpha\left(\tau_{1}\right) \tau_{1}-\alpha\left(\tau_{2}\right) \tau_{2}\right\} \omega+\left\{\beta\left(\tau_{1}\right) \tau_{1}\right.\right. \\
\left.\left.\quad-\beta\left(\tau_{2}\right) \tau_{2}\right\}\right] p(\omega) d \omega \ldots \ldots \ldots \ldots \ldots \ldots \ldots \ldots .(1
\end{aligned}
$$

が得られる。この式から共分散は $\ddot{z}(t)$ の組成関数であ る余弦関数に含まれる位相差とは無関倸汇定まることが 知られる。式 (12) において $\ddot{z}(t)$ の振動数特性が時間 的に変化しないとき,すなわち $\alpha(\tau)=1, \beta(\tau)=0$ であ るときは当然のことながら後藤らの解 ${ }^{1)}$ と一致する。 $\ddot{z}(t)$ の分散 $\sigma_{\ddot{z}}{ }^{2}(t)$ は上式において $\tau_{1}=\tau_{2}=t$ とおくこ とにより，

$$
\sigma_{\ddot{z}}{ }^{2}(t)=a^{2} \psi^{2}(t) / 2
$$

をうる。このことは振幅の時閒的変化とスペクトル密度 のそれとが独立であるとする式 (2) で与えられる地震波 の分散は，スペクトル密度が時間的にいかに変化しよう と, 強さの時間的変化を表わす確定関数のみによって与 えられることを意味している。

\section{（4） $\ddot{z}(\boldsymbol{t})$ の振幅の政率密度関数 $\boldsymbol{p}\{\ddot{z}(\boldsymbol{t})\}$}

$\ddot{z}(t)$ の振幅の確率密度関数 $p\{\ddot{z}(t)\}$ は式 (2) に中 心極限定理を用いることにより，平均值が 0 で分散が式 (13)で与えられる正規分布にしたがうことがわかる。す なわち $p\{\ddot{z}(t)\}$ は，

$$
p\{\ddot{z}(t)\}=\frac{1}{a \sqrt{\pi} \psi^{\prime}(t)} \cdot \exp \left[-\frac{\ddot{z}^{2}(t)}{a^{2} \psi^{\prime}(t)}\right] . .
$$

で与えられる。

\section{(5) $\boldsymbol{\phi}(\boldsymbol{t}), \boldsymbol{\alpha}(\boldsymbol{t}), \boldsymbol{\beta}(\boldsymbol{t}), \boldsymbol{p}(\boldsymbol{\omega})$ の表現}

以上までの検討においては $\psi(t)$ などの確定関数を一 般的な形で表現してきたが，式(2)で表わされるような 振幅特性とともに振動数特性が時間的に変化する地震動

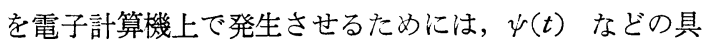
体的な関数形を設定しなければならない。

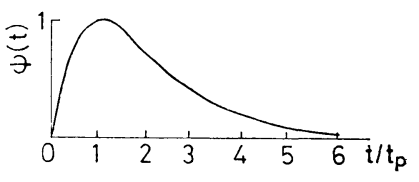

Fig. 6 人工地震波の shape function

$\dot{\psi}(t)$ については多くの実地震記録にあてはまるよう な解析関数を見出すことは困難であるが，次に示す関数 形は遠地地震の特徴を比較的よく表わしているとして， しばしば使われる形である (Fig. 6 参照)。

$$
\psi^{\prime}(t)=\frac{t}{t_{p}} \cdot \exp \left(1-\frac{t}{t_{p}}\right) \cdot U(t)
$$

ここに, $t_{p}$ は $\psi(t)$ が最大となる時刻, $U(t)$ は unit step function を表わす。本文では振幅特性の非定常性 を考える場合には $\psi(t)$ として上式を用いることにし， 振動数特性の非定常性のみに注目する場合には $\psi(t) \equiv 1$ とし，振幅特性を定常として解析した。

式 (3) 中の $\omega_{n}$ の確率密度関数 $p(\omega)$ 江式 (4) で表 わされるように, $g(\omega, \phi, t)$ のスペクトル密度 $S_{g}(\omega)$ と 相似形である。したがって $p(\omega)$ の形状は $S_{g}(\omega)$ を参 考にして決定すればよいことになるが，3.で見たように 個々の地震のスペクトルはかなり複雑な形をしている。 しかしながら地震力を構造物に伝える地盤る簡単化すれ ば1つの振動系と考えられるので， $S_{g}(\omega)$ したがって $p(\omega)$ を唯一のピークを持つ滑らかな曲線で近似的に次 式のように表現することにする。

$$
p(\omega)=\left\{\begin{array}{ll}
0 & : \omega<\omega_{s} \\
\frac{4\left(\omega-\omega_{s}\right)^{2}}{\omega_{q}^{3}} \cdot \exp \left\{-\frac{2\left(\omega-\omega_{s}\right)}{\omega_{q}}\right\}: \omega \geqq \omega_{s}
\end{array}\right\}
$$

上式は Fig. 7 に示すように $\omega_{p}\left(=\omega_{s}+\omega_{q}\right)$ なる円振 動数でピークを有するが，この曲線は 3. の地震記録の スペクトル密度を包括的にとらえた形状，もしくはその 包絡線とみなしうるので，以下の解析では $p(\omega)$ を上式 で与えるものとする。

スペクトル密度の時間的変化を表わす関数である $\alpha(t)$ と $\beta(t)$ については種々の表現法が考えられるが，3.に おける非定常スペクトル密度 $S_{N}(\omega, t)$ の時間的変化の 特徵を表わす最も簡単な場合として次式を考えることに

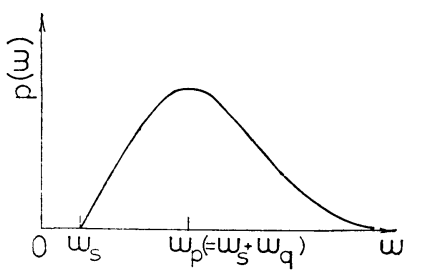

Fig. 7 人工地震発生に用いた振動数の確率密度関数 
する。すなうち，

$$
\alpha(t)=\exp (\gamma t), \beta(t)=\delta t
$$

Fig. 8 に，上式によって与えら礼る 関数によって時間とともに変化するスへ クトル密度の一例を示した。罒示された いるグラフはいずれも時間の経過上とも に低い振動数成分が卓越する場合である が，てある、は $\delta$ の符号を逆にするこ とにより, 逆汇高い成分肪優勢となるス ペクトル密寞在表わ寸こともできる。

\section{（5）スペクトル密度が喑間的に変化 する人工地需波の加速度記録}

式（2）によって発生させた。スペクト

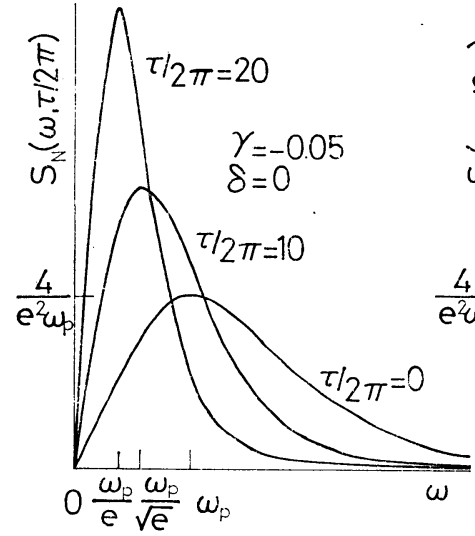

(a) type I

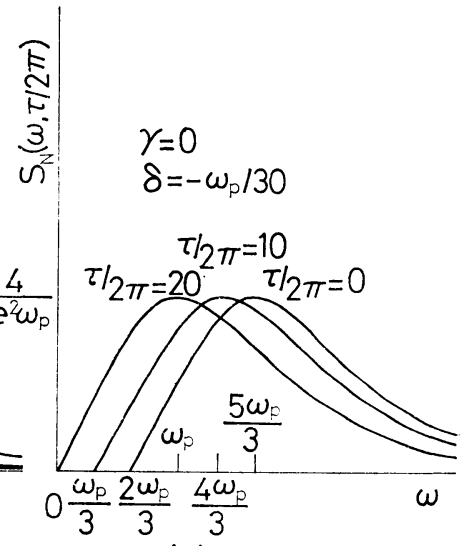

(b) type II

Fig. 8 穆間とともに変化するスベクトル密度 ル密度が時閒上上马に変化する人工地震波の加速度記録 の一例を Fig. 9 に示した。去た人工讪露発発生する際 に用いたパシメータをTable 2 に示す。図の蟥㸓は

Table 2 人工地霞を発生する際に用いたバラメータの值

\begin{tabular}{|c|c|c|c|}
\hline 記録名 & $r$ & $\delta$ & スヘクトル密度っ㭙間的変化つ型 \\
\hline$E-1$ & -0.139 & 0 & ( a) \\
\hline$E-2$ & 0.017 & & Ib) \\
\hline $\mathrm{E}-3$ & & 0.2 & II a) \\
\hline $\mathrm{E}-4$ & 0 & -0.2 & II b) \\
\hline $\mathrm{E}-5$ & & 0 & - \\
\hline
\end{tabular}

構造物の固有円振動数で無次元化された時間音, また檤 軸は構造物の降北加速度でもって無次元化された加速度 を表わす。なお shape function は時間にかかかららず一 定としてある。同図より先に述べた方法によって発生さ せた人工地震波の振動数特性が，ほぼ期待したと㧍り時 間とともに変化している様子がわかる。すなわら人工地 震 E-1 に拉いては時間の経過上と汇高、振動数成分 が卓越するようになっており, またややランダム性が増 していること，E-2 においては逆に低振動数成分が増 し, やや正弦波形に近べくこと，E-3 では E-1 と同じ く高振動数成分が多くなるが，そのランダム性には大き な变化が見られないこと，E-4では時間とともに低い振 動数成分が優勢となっているが，E-3 の場合と同に゙くそ のランダム性はあまり変わらないこと, E-5 は卓越振動 数成分, ランダム性ともにほぼ定常々みなしうること。 また E-1 から5のいずれの振幅特性もほぼ定常である こと,などである。以上のことから式 (2) によって発生 される人工地震波は, そのスペクトル密度の時間的変化 の様子が任意に変えられること, 地震波発生の際に用い る数個の乱数1)を取り換えることにより，同一の確率統 計的性質を有小るこのような人工地震波を数多く発生さ せることが可能であること，したがって，この人工地震

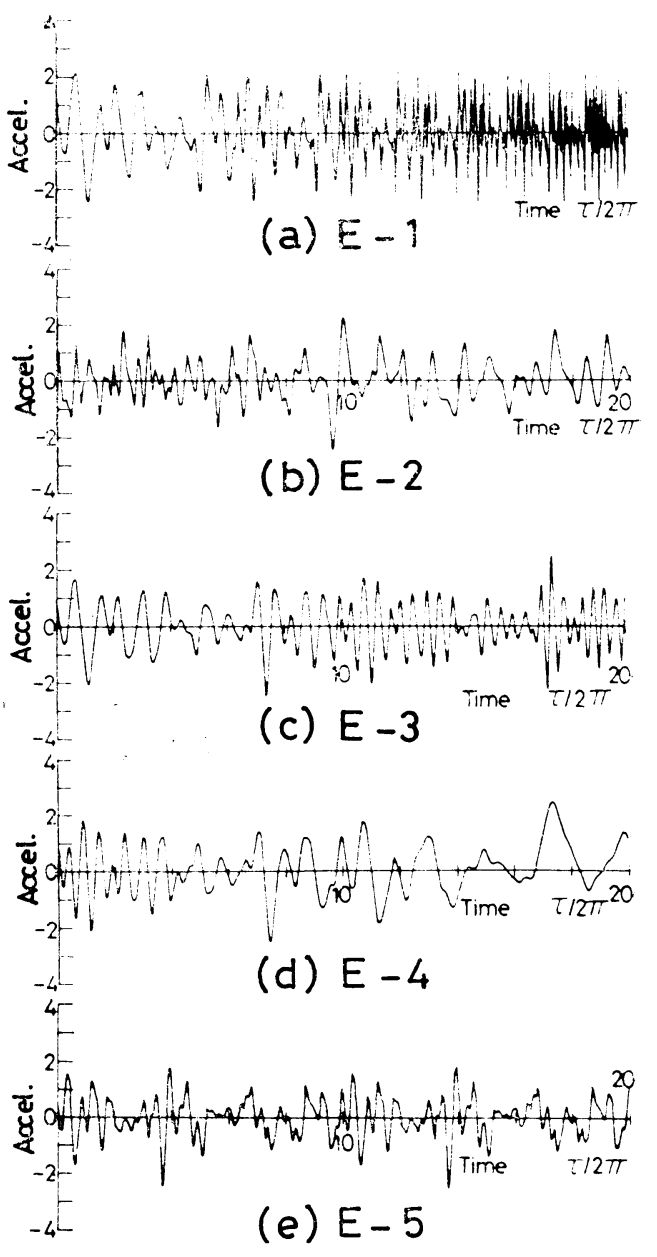

Fig. 9 スペクトル密度が時間とともに変化する人工地震波

波は, 地震動のスペクトル密度の時間的変化が構造物に 及ぼす影響を確率統計的に検討していくための入力地震 波として有用で沙ること，が明らかとなった。 


\section{5. 結論}

この研究は，従来地震波形の振幅特性に主として重点 が置かれていた非定常性の問題をその振動数特性にまで 按張したものであり，局所スペクトル密度の概念を用い て実地震記録の解析を行い，地震灾答解析において問題 となる加速度振幅の比較的大きな部分に限定しても，地 震動のスペクトル密度は時間とともに変化している場合 が多いことを示したものである。をた解析結果をもとに スペクトル密度の時間的変化の様子分類するととも に，そのような変化をする地震記録を人工的に発生させ る一方法を提案した。その結果得られた成果要約する と次のようである。

（1）局所スペクトル密度の概念变用いることによ り，地震動のスペクトル密度の時間的変化の様子を明ら かにすることができる。ただし本方法では元つ加速度記 録からある継続時間を持つ部分記録を取り出し解祈する が，この方法には継続時間内での地震動の確率統計的性 質の定常性と，有限記録を解析することにより生ずるス ペクトル密度の形状の変形しいう 200 問題点がある。 本解析の範囲では継続時間を 5 秒ととることによりほぼ 満足しらる程度でこの問題点を克服しうる。なた本解析 法では地震動の持つ確率統計的な諸性質が時間に関して ゆっくりと变化するという仮定を基に出発しているの で，新潟地震の記録のように加速度記録に明らかに確率 統計量が激変していると思われる時刻の存在する場合に は，その時刻において記録を分割したのち本方法を用い ればよい結果を得ることができる。

（2）地震記録のスペクトル密度の時間的変化の様子 は各記録によってかなり異っているが，変化のパターン を包括的に上らえると，次に示す 4 通りに大別できる。 a) 時間の経過とともに高い振動数成分が卓越する。b) 逆に低い成分が優勢となる。c）高い成分が卓越したり, 低い成分が卓越したりする。d）卓越振動数はほとんど 変わらない。

（3）地震記録の規準化したスペクトル密度の形状の 時間的変化を包括的にとらえると, 卓越振動数が低くな るにつれてランダム波形から正弦波形に近づく場合と， 時間にかかわらずほぼ合同な形で，ただその振動数領域 のみが変わる場合の両者がある。

（4）振幅特性や振動数特性の時間的变化を考慮した 地震波形は，振幅特性のみを規定する時間に関する確定 関数と, この関数上は独立で振動数成分のみが時間とと もに変化する確率過程の積として模式表示することがで きる。

（5）本方法により発生させたスペクトル密度が時間
とともに変化する人工地震波は，パラメータを適当に選 ぶことによりスペクトル密度の時間的変化の様子を任意 に変えうること，地震波発生の際に用いる数個の乱数を 取り換元ることにより同一の確率統計的性質を有する地 震波を電子計算機上で数多く発生させることができるこ とから, 地震動のスペクトル密度の時間的変化が構造物 の応答に及ぼす影響を確摔統計的に検討していくための 入力地震波となりうる。

（6）今後解決されるべき問題点は以下のようであ る。すなわち構造物の応答には入力地震動の卓越振動数 とともに振幅特性が大きな影響を及ぼすものと考えられ るので，今後は両者の洔間的変化を同時に検討すること も必要である。また, スペクトル密度の時間的変化の型 と震源距離との関係については, 震源にきわ的て近い地 震記録のスペクトル密度は時間的変化が比較的少ないと いうこと，地震の規模が大きくて震源距離の長い記録に ついては, 波動の地盤内に执ける複雑な反射屈折などを 反映してその卓越振動数が時間とともにかなり変化方る こと,などの傾向をとらえることができた。さらに詳細 なスペクトル密度の時間的変化の型と地盤条件や震源距 離などとの関係については，今徭より多くの記録につい ての解析に待たねばならない。

最後に本研究実施に際してご討議ならびに有益なご助 言をいただいた京都大学 傹田弘行助教授, 数值計算に おいて助力を受けた元京都大学大学院学生 (現神戸市役 所） 新谷瑞穂氏に感謝する次第である。また地震記録 の一部は京都大学 土忮憲三助教授に提供していただい た。ここに記して感謝の意を表する次第である。なお， 本研究の数值計算は京都大学大型計算機センターの FACOM 230-75 によったことを付記する。

\section{参考文献}

1）後滕尚男・土岐憲三・秋吉 卓：電子訫算機による邖震設 計用の人工地震波形に関する研究, 日本地震工学シンポジ ウム (1966) 講演集, 昭 41.10 , pp. 25 30.

2）土岐憲三：地震動のシミュレーションとその応用, 京都大 学防災研究所年報, 第 11 号 A, 昭 43, pp. 291 303.

3）山原 浩：地震の振動特性を考虑した地震時の地動の推定 （その 1）—地震のパワーとスペクトル特性の時間的変 化, 日本建築学会論文報告集, 第 175 号, 昭 45.9, pp. 31 $\sim 37$.

4）山原 浩：地震時の振動特性を考虑した地震時の地動の推 定 (その 2) 一地層の物理モデル置換と地震時の地動の 推定一, 日本建築学会論文報告集, 第 176 号, 昭 45.10 , pp. $51 \sim 57$.

5) Trifunac, M.D.: Response Envelope Spectrum and Interpretation of Strong Earthquake Ground Motion, Bulletin of the Seismological Society of America, Vol. 61, No. 2, April, 1971, pp. 343 356.

6) Trifunac, M.D.: A Method for Synthesizing Realistic Strong Ground Motion, Bulletin of the Seismological Society of America, Vol. 61, No. 6, December, 1971, pp. 1739 1753.

7) Page, C.H.: Instantaneous Power Spectra, Jour. of 
Appl. Phys. 23, Jan., 1952, pp. 103 106.

8) Priestley, M.B.: Evolutionary Spectra and NonStationary Processes, Jour. of Royal Statistical Society, B 27, 1965, pp. 204 237.
9) Lin, Y. K.: Probabilistic Theory of Structural Dynamics, McGraw-Hill Book Company, 1967, p. 60 .

(1974. 9. 18 - 受付) 